\title{
Comparative Ergonomic Assessment of the Male and Female Farm Workers Involved in Rice Cultivation
}

\author{
Pragya Ojha $^{1^{*}}$ and Seema Kwatra ${ }^{2}$ \\ ${ }^{1}$ Department of Family Resource Management, College of Home Science, ND University of \\ Agriculture \& Technology, Kumarganj, Faizabad (Uttarpradesh), India \\ ${ }^{2}$ Department of Family Resource Management, College of Home Science, GB Pant University of \\ Agriculture \& Technology, Pantnagar (Uttarakhand), India \\ *Corresponding author
}

\begin{tabular}{|c|c|}
\hline & A B S T R A C T \\
\hline & $\begin{array}{l}\text { In Indian agricultural farming, numerous drudgery prone activities are involved. Rice } \\
\text { uprooting and transplanting are the most common example of these kinds of drudgery } \\
\text { prone activities. Indian farmers are highly associated with these tasks and they perform a }\end{array}$ \\
\hline Keywords & $\begin{array}{l}\text { sequential work through manual efforts. In some areas of India, the improved method of } \\
\text { uprooting and transplanting are being used but due to lack of awareness and information }\end{array}$ \\
\hline $\begin{array}{l}\text { Center of gravity, } \\
\text { Drudgery, } \\
\text { Ergonomical } \\
\text { evaluation, Farm } \\
\text { workers, Posture. }\end{array}$ & $\begin{array}{l}\text { manual performance of these activities are much common. In the present investigation } \\
\text { efforts have been made to compare the ergonomical parameters and the rate of human } \\
\text { drudgery among male and female farm workers, during manual hand uprooting and } \\
\text { transplanting with the improved method. For the ergonomical evaluation, twenty female } \\
\text { and twenty male subjects were selected in the age group of } 20 \text { - } 55 \text { years. Physiological }\end{array}$ \\
\hline Article Info & parameters like HR, Blood Pressure, $\mathrm{VO}_{2}$ max and hand grip strength etc. were measured \\
\hline $\begin{array}{l}\text { Accepted: } \\
10 \text { July } 2017 \\
\text { Available Online: } \\
10 \text { September } 2017\end{array}$ & $\begin{array}{l}\text { was used to assess the deviation in CG in various working postures from neutral posture. It } \\
\text { was observed that the center of gravity in various working postures was significantly } \\
\text { deviated from neutral posture. The percentage reduction in grip strength was also observed } \\
\text { to be lower in improved method compared to traditional method. From this study it has }\end{array}$ \\
\hline & $\begin{array}{l}\text { been recommended that improved method of uprooting and transplanting can significantly } \\
\text { reduce the cost of drudgery among farmers and workers should avoid bad work postures as } \\
\text { far as possible during their work for reducing postural stress. }\end{array}$ \\
\hline
\end{tabular}

\section{Introduction}

Rice is cultivated in 113 countries and it is the staple food of more than 50 percent population of the world. About 90 percent rice area exists in Asia (Das, 2012). More than three- fourth of Uttarakhand's total population depend on agriculture for their livelihood and the economy is predominantly dependent on mountain agriculture. However, the land holding are small and fragmented and irrigation facilities are limited. The state faces the challenges of promoting livelihood to retain people through local employment and income generation and to enhance their quality of life (Mittal et al., 2008). In Asian countries, farm workers adopt various types of transplanting methods. But manual rice transplanting is the most common method of rice crop establishment, particularly during 
rabi season, which is too much laborious, cumbersome, time consuming and entails a lot of expenditure on raising, uprooting and transplanting of nursery (Awan et al., 2008). Manual paddy transplanting is a labour intensive operation which requires 200-250 man-h/ha. During peak season labourers are not available (Das, 2012). Agricultural production patterns affect the timing of peak labour demands and the nature of tasks involved. In rural areas, affordability is the key constraint to the use of mechanized processes. Many women lack cash to pay for mechanical processing in rural areas is often relatively expensive. Also, although manual processes take up valuable time, some can be fitted in around other chore (Joshi et al., 2012).

During manual uprooting and transplanting, Indian farmers are exposed to musculoskeletal disorders as well as drudgery due to the repetitive bending as well as the awkward posture needed in performing the operations. It is also well recognized by Grandjean and Hunting (1977), that inadequate posture, when adopted for long periods, cause bodily damage and ill health. High repetition, excessive forces and awkward postures are the major causes of musculoskeletal disorder and complaints in industry and industrializing countries (Nordander et al., 2008, Kumudini et al., 2009, Westgaard 2000).

Working conditions of agricultural workers are extremely difficult due to severe environmental conditions, long working hours, strenuous work and the use of improper equipment (Kar et al., 2012). Now a day, to ease the uprooting and transplanting work and enhance the productivity, mechanization is the most appropriate option for the farmers which can significantly reduce their musculoskeletal disorders and drudgery. The present investigation is aimed to assess and compare the physiological parameters of the male and female agricultural workers during uprooting and transplanting operations. Also, efforts have been made to analyze different postures and measure the deviation of center of gravity during various working postures adopted by those workers.

\section{Materials and Methods}

\section{Selection of site and subjects}

The proposed study has been conducted in Tarai agro- climatic zone of Udham Singh Nagar district of Uttarakhand state, India in the month of June- July. The study was conducted on 20 male and 20 female subjects in the age group of 20-55 years were selected because they usually attain their highest strength level between 20-45 years (Mc Ardle et al., 2001). The paddy uprooting and transplanting operations were done for 7:00A.M.12:30 P.M. and 2:00 P.M. to 5:30 P.M. For the mechanized uprooting mat nursery was planted by the agricultural workers and for mechanical rice transplanting power operated eight row paddy transplanter was adopted from the Department of Farm Machinery \& Power Engineering, College of Technology, GBPUA\&T, Pantnagar.

\section{Measurement of height}

Height was taken with the help of an anthropometric rod. At first the subjects were asked to stand straight on the floor and then the vertical distance from floor to vertex (maximum bulge portion of the head) was measured.

\section{Measurement of weight}

Weight of the subjects was taken by a portable weighing machine. Subjects were asked to stand straight on weighing machine in minimum clothing and reading was taking from the scale of machine. 


\section{Determination of BMI}

The body mass index of subjects was calculated by dividing square of height $(\mathrm{m} 2)$ to weight $(\mathrm{kg})$.

\section{Measurement of blood pressure and heart rate}

The blood pressure of the samples was measured by Digital blood pressure monitor and the heart rate was measured by Polar heart rate monitor and recorded as HR=beat/ $\min$.

\section{Determination of oxygen consumption rate $\left(\mathrm{VO}_{2}\right)$}

The oxygen consumption rate was calculated by following formula:

$\mathrm{VO}_{2}=0.023 \times$ Body weight $(\mathrm{kg})-0.034 \times$ Age (years) +1.65

\section{Measurement of hand grip strength}

Before and after performance of the uprooting and transplanting activity, the static grip strength measurement was performed by using hand grip dynamometer. This hand dynamometer features a dual pointer system to retain the minimum effort. The testing range on dual scale is $(0-100) \mathrm{kg} /(0-200) \mathrm{lb}$. Before taking the measurement, the subjects were requested to stand in a comfortable position. The subjects were asked to squeeze the dynamometer as hard as possible without moving the rest of the body. Thus the final grip strength was measured for both hand and the reading was taken from the dynamometer scale, when pointer was no longer moved. The percentage change in grip strength was calculated using the following formula,

Change in grip strength $(\%)=\mathrm{Sr}-\mathrm{Sw} \mathrm{x}$ $100 / \mathrm{Sr}$
Where,

$\mathrm{Sr}=$ Strength of muscles at rest

$\mathrm{Sw}=$ Strength of muscles after work

Decreased grip strength was interpreted as grip fatigue of the muscles.

\section{Postural analysis}

The whole body center of gravity (CG) of the workers were determined by segmental method in normal erect posture, which was taken as reference posture and in other postures adopted by farm workers during traditional and mechanized method of uprooting and transplanting. The location of CG was compared by the following equations:

Percentage of location of $C G=$ Length of $C G$ from ground/Total length of the body x 100

\section{Statistical analysis}

Two-sample t-test assuming unequal variances was performed among the male and female rice cultivators to find out whether there is any significant difference in ergonomical parameters of workers for the chosen level of significance $(\mathrm{P}<0.0001)$. Statistical analysis was performed using the statistical package IBM SPSS statistics $($ Version $=20)$.

\section{Results and Discussion}

It was observed from the results that there was a significant difference $(\mathrm{p}<0.0001)$ in physiological characteristics of male and female respondents (Table 1). The mean HR max of male and female farm workers was found $181.35 \pm 9.67$ beats $/ \mathrm{min}$ and 188.2 \pm 7.27 beats/min respectively. The $\mathrm{VO}_{2}$ max of male workers was $2.17 \pm 1.67 \mathrm{l} /$ min whereas it was observed $1.82 \pm 0.41 \mathrm{l} / \mathrm{min}$ of female workers. 
The average height was $166 \pm 2.95 \mathrm{~cm}$ of male farmers and $151.62 \pm 3.60 \mathrm{~cm}$ of female agricultural workers. The mean value of body weight of male and female farm workers was $65.32 \pm 3.95 \mathrm{~kg}$ and $51.11 \pm 3.34 \mathrm{~kg}$ respectively whereas the average rate of BMI was calculated $24.66 \pm 2.75 \mathrm{~kg} / \mathrm{m}^{2}$ of male workers and $22.05 \pm 1.45 \mathrm{Kg} / \mathrm{m}^{2}$ of female workers. Both, male and female farm workers have the normal range of Blood pressure i.e. $119.3 / 82 \pm 10.93 / 8.39 \quad \mathrm{mmHg}$ and $117.5 / 80 \pm 10.60 / 14.14 \mathrm{mmHg}$ respectively.

The power of handgrip is the result of forceful flexion of all finger joints with maximum voluntary force that the subject is able to exert under normal biokinetic conditions (Richards et al., 1996; Bohannon 1997) which uses several muscles in the hand and forearm (Bassey and Harries 1993). Hand grip is often used as an indicator of overall physical strength (Foo 2007), hand and forearm muscles performance (Nwuga 1975) and as a functional index of nutritional status (Vaz et al., 1996, Jeejeebhoy 1998, Manandhar 1999, Chilima and islam 2001, Pieterse et al., 2002) and physical performance (Samson et al., 2000, Onder et al., 2002) etc. The results revealed that there was significant difference between $(<0.0001)$ the handgrip strength of male and female farm workers while performing the uprooting and transplanting activities both with traditional and improved method is shown in tables 2 and 3 .

As depicted in table 4, during the uprooting activity, the percentage change of grip strength of right hand of male and female farm workers in improved over traditional method was 91.51 percent and 6.67 percent respectively whereas percent deviation in left hand of hand grip strength of male agricultural workers was 80.55 percent and 35.58 percent of female agricultural workers. Further, during transplanting operation, the percentage change in right hand grip strength of male farm workers was 76.32 percent and
18.66 percent of female agricultural workers whereas, in improved over traditional method, the grip strength of left hand of male and female agricultural workers was deviated 9.79 percent and 53.15 percent respectively. The grip strength of both hands of male and female farm workers has reduced after performing the uprooting and transplanting tasks with both traditional and improved methods. But the percentage reduction in grip strength was observed to be lower in improved method compared to traditional method (Table 4).

A good working posture is one which can be sustained with a minimum static muscular effort and in which it is possible to perform the task more effectively and with least muscular effort (Taneja et al., 2012). The location of CG of male and female workers was determined in normal standing posture which was taken as reference posture and in three various working postures i.e. standing, bending and sitting during the manual and improved method of uprooting and transplanting. From table 5, it was observed that the position of CG of male and female farm workers in normal standing posture was $60 \pm 1.32$ and $55.39 \pm 1.67$ respectively.

In standing while manual uprooting, the location of center of gravity of the male respondents were 4 percent $(57.6 \pm 0.98)$ deviated from normal standing posture whereas in the case of female workers it was shifted to 6.70 percent $(51.68 \pm 1.93)$. During manual uprooting, male and female

Farm workers, generally adopt bending posture. In bending position, the CG of male and female respondents was shifted to 27.68 percent $(43.39 \pm 2.39)$ and 25.33 percent (41.36 \pm 3.05$)$ respectively. Further, highest deviation of CG was observed, when the farm workers adopt sitting posture. The CG of male farm workers was calculated as 41.37 percent (35.18 \pm 3.78$)$ during manual 
uprooting when they adopt sitting working posture and $\mathrm{CG}$ of female agricultural workers was observed as 44.11 percent (30.96 \pm 3.67$)$.

Table.1 Comparison of physical characteristics between male and female agriculture workers

\begin{tabular}{|c|c|c|c|}
\hline Parameters & Male $(\mathbf{n}=\mathbf{2 0})$ & Female $(\mathbf{n}=\mathbf{2 0})$ & t value \\
\hline Height $(\mathrm{cm})$ & $166 \pm 2.95$ & $151.62 \pm 3.60$ & $13.81^{* *}$ \\
\hline Weight $(\mathrm{kg})$ & $65.32 \pm 3.95$ & $51.11 \pm 3.34$ & $12.28^{* *}$ \\
\hline Body Mass Index $(\mathrm{Kg} / \mathrm{m} 2)$ & $24.66 \pm 2.75$ & $22.05 \pm 1.45$ & $3.75^{* *}$ \\
\hline Blood Pressure $(\mathrm{mmHg})$ & $119.3 / 82 \pm 10.93 / 8.39$ & $117.5 / 80 \pm 10.60 / 14.14$ & $0.52^{* * / 0.54 * *}$ \\
\hline HR rest, beats/min & $74.69 \pm 2.78$ & $72.96 \pm 1.91$ & $2.29^{* *}$ \\
\hline HR max, beats/min & $181.35 \pm 9.67$ & $188.2 \pm 7.27$ & $2.53^{* *}$ \\
\hline $\mathrm{VO}_{2 \text { rest }}(1 / \mathrm{min})$ & $0.20 \pm 1.26$ & $0.16 \pm 0.03$ & $0.14^{* *}$ \\
\hline $\mathrm{VO}_{2 \max }(1 / \mathrm{min})$ & $2.17 \pm 1.67$ & $1.82 \pm 0.41$ & $0.91^{* *}$ \\
\hline
\end{tabular}

** Significant at $1 \%$ level $(<0.0001)$

Table.2 Comparison of hand grip strength of male and female subjects in traditional paddy Uprooting and transplanting

\begin{tabular}{|c|c|c|c|c|c|c|c|c|}
\hline \multirow[t]{4}{*}{ Parameters } & \multicolumn{8}{|c|}{ Traditional method } \\
\hline & \multicolumn{4}{|c|}{ Uprooting } & \multicolumn{4}{|c|}{ Transplanting } \\
\hline & \multicolumn{2}{|c|}{ Right Hand } & \multicolumn{2}{|c|}{ Left hand } & \multicolumn{2}{|c|}{ Right Hand } & \multicolumn{2}{|c|}{ Left hand } \\
\hline & Male & Female & Male & Female & Male & Female & Male & Female \\
\hline Before work & $23.47 \pm 1.96$ & $19.35 \pm 1.76$ & $20.06 \pm 1.17$ & $17.38 \pm 1.27$ & $24.13 \pm 1.70$ & $19.65 \pm 1.98$ & $21.21 \pm 1.74$ & $17.35 \pm 1.93$ \\
\hline After work & $22.63 \pm 1.66$ & $18.54 \pm 1.32$ & $19.41 \pm 1.15$ & $16.35 \pm 0.98$ & $23.08 \pm 1.42$ & $18.65 \pm 1.47$ & $20.71 \pm 1.55$ & $16.01 \pm 2.01$ \\
\hline $\begin{array}{l}\text { Percentage change in } \\
\text { grip strength }\end{array}$ & 3.58 & 4.18 & 3.24 & 5.93 & 4.35 & 5.09 & 2.35 & 7.72 \\
\hline t value & \multicolumn{2}{|c|}{$8.62^{* *}$} & \multicolumn{2}{|c|}{$\frac{1}{9.05^{* *}}$} & \multicolumn{2}{|c|}{$9.69^{* *}$} & \multicolumn{2}{|c|}{8.28} \\
\hline
\end{tabular}

** Significant at $1 \%$ level $(<0.0001)$

Table.3 Comparison of hand grip strength of male and female subjects in improved paddy Uprooting and transplanting

\begin{tabular}{|c|c|c|c|c|c|c|c|c|}
\hline \multirow[t]{4}{*}{ Parameters } & \multicolumn{8}{|c|}{ Improved method } \\
\hline & \multicolumn{4}{|c|}{ Uprooting } & \multicolumn{4}{|c|}{ Transplanting } \\
\hline & \multicolumn{2}{|c|}{ Right Hand } & \multicolumn{2}{|c|}{ Left hand } & \multicolumn{2}{|c|}{ Right Hand } & \multicolumn{2}{|c|}{ Left hand } \\
\hline & Male & Female & Male & Female & Male & Female & Male & Female \\
\hline Before work & $24.48 \pm 0.95$ & $18.95 \pm 0.79$ & $22.16 \pm 1.97$ & $16.75 \pm 1.67$ & $24.23 \pm 1.51$ & $19.78 \pm 1.45$ & $23.53 \pm 1.50$ & $17.97 \pm 1.96$ \\
\hline After work & $24.23 \pm 1.60$ & $18.21 \pm 1.02$ & $22.02 \pm 1.78$ & $16.11 \pm 1.45$ & $23.98 \pm 1.90$ & $18.96 \pm 1.69$ & $23.03 \pm 2.00$ & $17.32 \pm 1.56$ \\
\hline $\begin{array}{l}\text { Percentage change } \\
\text { in grip strength }\end{array}$ & 1.02 & 3.90 & 0.63 & 3.82 & 1.03 & 4.14 & 2.12 & 3.62 \\
\hline $\mathrm{t}$ value & \multicolumn{2}{|c|}{$14.18^{* *}$} & \multicolumn{2}{|c|}{$11.51^{* * *}$} & \multicolumn{2}{|c|}{$8.82^{* *}$} & \multicolumn{2}{|c|}{$10.06^{* * *}$} \\
\hline
\end{tabular}

** Significant at $1 \%$ level $(<0.0001)$

Table.4 Percentage Change in grip strength of farm workers while performing uprooting and transplanting activities in improved over traditional method

Percentage change in improved over traditional method

\begin{tabular}{|c|c|c|c|c|c|c|c|}
\hline \multicolumn{4}{|c|}{ Uprooting } & \multicolumn{4}{c|}{ Transplanting } \\
\hline \multicolumn{2}{|c|}{ Right Hand } & \multicolumn{2}{c|}{ Left Hand } & \multicolumn{2}{c|}{ Right Hand } & \multicolumn{2}{c|}{ Left Hand } \\
\hline Male & Female & Male & Female & Male & Female & Male & Female \\
\hline 91.51 & 6.67 & 80.55 & 35.58 & 76.32 & 18.66 & 9.79 & 53.15 \\
\hline
\end{tabular}


Table.5 Percent deviation of center of gravity in various working posture during Uprooting and transplanting

\begin{tabular}{|c|c|c|c|c|c|}
\hline $\begin{array}{c}\text { Different body } \\
\text { postures adopted } \\
\text { by respondents }\end{array}$ & $\begin{array}{c}\text { CG of } \\
\text { male } \\
\text { workers } \\
(\mathbf{n = 2 0})\end{array}$ & $\begin{array}{c}\text { Percent } \\
\text { deviation } \\
\text { From normal }\end{array}$ & $\begin{array}{c}\text { CG of } \\
\text { female } \\
\text { workers } \\
\text { (n=20) }\end{array}$ & $\begin{array}{c}\text { Percent } \\
\text { deviation } \\
\text { from normal }\end{array}$ & t value \\
\hline Normal standing & $60 \pm 1.32$ & - & $55.39 \pm 1.67$ & - & $9.68^{* *}$ \\
\hline $\begin{array}{c}\text { manual uprooting } \\
\bullet \quad \text { Standing }\end{array}$ & $57.6 \pm 0.98$ & 4 & $51.68 \pm 1.93$ & 6.70 & $12.23^{* *}$ \\
\hline$\bullet \quad$ Bending & $43.39 \pm 2.39$ & 27.68 & $41.36 \pm 3.05$ & 25.33 & $2.34^{* * *}$ \\
\hline$\bullet \quad$ Sitting & $35.18 \pm 3.78$ & 41.37 & $30.96 \pm 3.67$ & 44.11 & $3.58^{* *}$ \\
\hline $\begin{array}{c}\text { Manual transplanting } \\
\bullet \quad \text { Standing }\end{array}$ & $56.9 \pm 1.25$ & 5.17 & $52.36 \pm 3.94$ & 5.54 & $4.91^{* *}$ \\
\hline • Bending & $45.78 \pm 3.89$ & 23.7 & $40.69 \pm 2.86$ & 26.54 & $4.71^{* *}$ \\
\hline $\begin{array}{c}\text { Bending in mechanical } \\
\text { uprooting }\end{array}$ & $45.15 \pm 2.76$ & 24.75 & $39.65 \pm 1.98$ & 28.42 & $7.24^{* *}$ \\
\hline $\begin{array}{c}\text { Sitting on the rice } \\
\text { transplanter }\end{array}$ & $77.16 \pm 2.95$ & -28.6 & $72.65 \pm 2.65$ & -31.16 & $5.08^{* *}$ \\
\hline
\end{tabular}

** Significant at $1 \%$ level $(<0.0001)$

During the operation of manual transplanting, male and female farm workers adopt standing and bending postures for longer duration of time and perform the activity in repetitive motion. In standing body posture the deviation of CG of male farm workers was observed as 5.17 percent $(56.9 \pm 1.25)$ whereas in female farm workers it was shifted to 5.54 percent (52.36 \pm 3.94$)$. During the bending position the location of CG of male and female farm workers was $23.7(45.78 \pm 3.89)$ and 26.54 (40.69 \pm 2.86$)$ respectively. Usually bending posture is adopted by the farm workers when they put the mat nursery on the paddy transplanter. It was observed that during bending in mechanical uprooting, the location of CG of male farm workers was shifted to 24.75 percent $(45.15 \pm 2.76)$ from the normal standing posture and in female workers it was deviated to 28.42 percent $(39.65 \pm 1.98)$. But during the performance of mechanical uprooting, the level of postural discomfort among male and female farm workers was very low because the workers adopt this body posture for few minutes i.e. not more than 5 minutes for the completion of one cycle whereas in manual uprooting the farm workers adopt the bending position for more than 45 minutes for the completion of one cycle. When the male and female farm workers perform the activity with eight row paddy transplanter in sitting posture the CG of male farm workers was deviated to -28.6 percent $(77.16 \pm 2.95)$ and CG of female farm workers was shifted to 31.16 percent $(72.65 \pm 2.65)$ which means the level of postural stress during mechanical transplanting was significantly reduced.

The handgrip strength determines the muscular strength of an individual (Foo 2007). The results revealed that the greater grip strength in male subjects represented greater muscular strength of them which may be due to greater activity level of male subjects that of their female counterpart. Singh et al., (2004) opined that characteristics of manually handling loads/ materials involve a variety of traditional postures like sitting, squatting, sitting cum bending, standing cum bending, erect standing etc. The ergonomic assessment of selected agricultural technologies also revealed that the improved equipments were economical in terms of time and energy and improved health and efficiency of farm women (Gupta, et al., 2002). 
Agrawal et al., (2004) studied the effect of linkage of ergonomic performance of agricultural workers. In posture extremes, muscles may not be able to produce the forces requires by the task, may place extreme stress on tendons and may put pressure on nerve tissue and blood vessels (Jumah and Nyame, 2004). From this investigation it has been concluded that in manual method of uprooting and transplanting, agricultural workers adopt traditional sitting, bending and squatting body postures with folded legs. This is directly associated to high postural stress and work performance of the farmers. As body joint angles and the location of center of gravity had lesser degree of deviation from the reference position during uprooting and transplanting operations, a lesser degree of postural stress was imposed in reference postures. Hence, the agricultural workers involved in uprooting and transplanting operation may be suggested to work with improved and mechanized method to lessen work related postural stress. Further in the future, the rice uprooting and transplanting practices can be improved through ergonomic intervention for higher productivity and reduced drudgery which will enhance the comfort and safety of the workers. There are possible ergonomic interventions that we identified to increase the value of this investigation is that repetition of work in uprooting and transplanting activity with traditional method, which causes musculoskeletal disorders, should be avoided. It also recommended brief intra work pauses should be taken by the farm workers to decrease fatigue in repetitive work in which the muscles can rest after experiencing a static load and a break after a period of continuous work. Muscular fatigue, level of drudgery, boredom and monotony of a job of agriculture workers can be reduced with the implementation of job or work rotation policy.

\section{References}

Agrawal, K.N., Thomad, E.V. and Satapath, K.K. 2004. Effect of linkage on ergonomical performance of agricultural workers of Meghalaya in pedal peddy thresher operation. Proceeding of International conference on emerging technologies of agricultural and food engineering. IIT Kharagpur, 271-277.

Awan, T.H., Ali, I., Safdar, M.E., Ahmad, M. and Akhtar, M.S. 2008. Comparison of parachute, line and traditional rice transplanting methods at farmer's field in rice Growing area. Pak. J. Agri. Sci., Vol. 45(4): 432-438.

Bassey, E.J., and Harries, U.J. 1993. Normal values for hand grip strength in 920 men and women aged over 65 years and longitudinal changes over 3 years in 620 survivors. Clin Sci 84:331- 337.

Bohannon, R.W., 1997. Reference values for extremity muscle strength obtained by handheld dynamometer from adults aged 20 to 79. Arch Phys Med Rehab, 78: 26-32.

Chilima, D.M., and Islam, S.J. 2001. Nutritional and hand grip strength of older adults in rural Malawi. Public Health Nutr, 9: 11-17.

Das, F.C., 2012. Status and Prospects of Mechanization in Rice. Rice Knowledge Management Portal. Available at http://www.rkmp.co.in (accessed July 2014).

Foo, L.H., 2007. Influence of body composition, muscle strength, diet and physical activity on total body and forearm bone mass in Chinese adolescent girls. $\mathrm{Br} J$ Nutr, 98: 1281- 1287.

Grandjean, E., and Hunting, W.1977. Ergonomics of posture-review of various problems of standing and sitting posture. Applied Ergonomics. 8: 135-140.

Gupta, P., Singhal, A., Singh, S., Sharma, P. and Jain, S. 2002. Drudgery faced by farm women in agriculture. Published in the proceeding of national seminar on dynamics of women in agriculture for national development, MP. University of agriculture and technology, Udaipur, India: 230-236.

Jeejeebhoy, K.N., 2012. Nutritional assessment. Gastroentrol, Clin North Am, 27: 347-369.

Joshi, P., Chandra, N., Sahoo, D.C. and Bhatt, J.C. 2012. Ergonomic assessment of postharvest threshing activity: A hill women concern. Humanizing work and work 
environment: Ergo- safety for all. Chapter 54: 397- 402.

Jumah, K.B., and Nyame, P.K. 2004. Relationship between load carrying on the head and cervical spondyloysis in Ghanaians. Proceeding of International conference on emerging technologies of agricultural and food engineering. IIT Kharagpur 14-17 December: 181-182.

Kar, S.K., Ghosh, S., Paul, R., De, S. and Dhara, P.C. 2012. Ergonomically Evaluation of Occupational Problems of Women Workers in Agricultural Tasks, International Journal of Basic and Applied Physiology. Vol 1(1): 103-108.

Kumudini, G., and Hasegawa, T. 2009. Workload and awkward posture problems among small-scale straberry farmers in Japan. $J$ Hum Ergol (Tokyo), 38(2): 81-87.

Manandhar, M.C., 1999. Under nutritional and impaired functional ability amongst elderly slum dwellers in Mumbai, India. Ph.D. Thesis, London school of hygience and tropical medicine.

Mc Ardle, W. D., Katch, F.I., Katch, and V. L. 2001. Exercise Physiology, 5th edition. Pennsylvania: Lippincott Williams and Wilkins publication.

Mittal, S., Tripathi, G., and Sethi, D. 2008. Development strategy for hill districts of Uttarakhand. Working paper no. 2017, Indian council for Research on International Economic Relations.

Nordander, C., Ohlsson, K., Balogh, I., Hansson, G.A., Axomon, A., Presson, R. and Skerfving, S. 2008. Gender differences in workers with identical repetitive industrial tasks: exposure and musculoskeletal disorders. Int Arch Occup Environ Health; 81(8): 939-947.

Nwuga, V., 1975. Grip strength and grip endurance in physical therapy students, Arch phys med rehab, 56: 296-299.
Onder, G., Penninx, B.W., Lapuerta, P., Fried, L.P., Ostir, G.V. and Guralnik, J.M. 2002. Changes in phycal performance over time in older women: the women's health and aging study. Journal of geronol Biological Science Med Sci, 57: 289-293.

Pieterse, S., Manandhar, M. \& Ismail S. 2002. The association between nutritional status and hand grip strength in older Rwandan refugees. Eur J clin Nutr, 56:933-939.

Richards, L., Olson, B. and Palmiter- Thomas, P. 1996. How forearm position affects grip strength. American Journal of Occupational Therapy, 50:133-139.

Samson, M.M., Meeuwsen, I.B., Crowe, A., Dessens, J.A., Duursma, S.A. and Verhaar, H.J. 2000. Relationships between physical performance measures age, height and body weight in healthy adults. Age and Aging, 29: 235- 242.

Singh, P.S., Gite, P.L. and Agrawal, M. 2004. Physiological workload of farmwomen in the operation of CIAF hanging type cleaner. Published in the proceeding of international conference on emerging technologies in agricultural and food engineering, IIT Kharagpur, 343-347.

Taneja, M., and Gandhi, S. 2012. Assessment of biomechanical stress in computer users. Humanizing work and work environment: Ergo- safety for all. Chapter 33: 276- 281.

Vaz, M., Thangam, S., Prabhu, A. and Shetty, P.S. 1996. Maximal voluntary contraction as a functional indicator of adult chronic under nutrition. Br J Nutr, 76: 9-15.

Westgaard, R.H., 2000. Work related musculoskeletal complaints: Some ergonomic challenges upon the start of a new century. Appl. Ergonomics 31: 569580 .

\section{How to cite this article:}

Pragya Ojha and Seema Kwatra. 2017. Comparative Ergonomic Assessment of the Male and Female Farm Workers Involved in Rice Cultivation. Int.J.Curr.Microbiol.App.Sci. 6(9): 3439-3446. doi: https://doi.org/10.20546/ijcmas.2017.609.422 